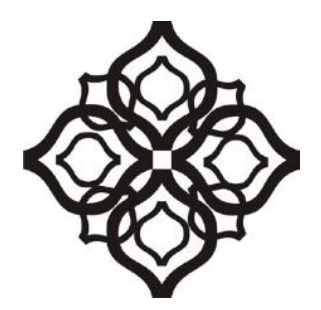

Shirkah

Journal of Economics and Business 
Shirkah: Journal of Economics and Business

Volume 5, No. 3, September-December 2020

ISSN: 2503-4235 (p); 2503-4243 (e)

\section{Table of Contents}

Institutional Quality and Sukuk Development: A Study of Five 286 OIC Countries

Nuhbatul Basyariah, Hadri Kusuma, Ibnu Qizam

Performance of GoFood MSEs Partnership: An Integration of

Entrepreneurial Orientation, Marketing Capabilities, and

Brand Orientation

Septi Kurnia Prastiwi, Asep Maulana Rohimat

Islamic Social Reporting Disclosure of Sharia Commercial

Banks in Indonesia: A Form of Social Responsibility

Riduwan, Lu'liyatul Mutmainah, Rofiul Wahyudi

Concentration and Specialization of Economic Activities in the 362

Kingdom of Saudi Arabia

Salim Bourchid Abdelkader, Hamidouche M'hamed, Abderrazak

Ahmed Zian

Indonesian Islamic Commercial Banks' Efficiency: A Stochastic 386 Frontier Analysis

Sylva Alif Rusmita, Devy Ariesta Putri

Islamic Economics Development in Indonesia: Reflection on

Contemporary Thoughts of Muslim Intellectuals

Zainal Abidin 


\title{
Concentration and Specialization of Economic Activities in the Kingdom of Saudi Arabia
}

\author{
Salim Bourchid Abdelkader \\ King Khalid University, Kingdom of Saudi Arabia \\ smoualdi@kku.edu.sa \\ Hamidouche M'hamed* \\ Djilali Bounaama University, Algeria \\ *Corresponding author: mah_hamdouche@yahoo.fr \\ Abderrazak Ahmed Zian \\ King Khalid University, Kingdom of Saudi Arabia \\ alawak@kku.edu.sa
}

\begin{abstract}
This study presents several indicators for understanding the structure of economic activities in terms of concentration and specialization in the Kingdom of Saudi Arabia. Subsequently, the theoretical description of the different notions of concentration and specialization relating to geographical or sectors aspect is applied to understand the equality in the distribution of wages and employment levels across the country. Thus, the authors have estimated the most important indexes used in a large part of the academic literature and which are most representative of concentration and distribution, such as the Gini, Herfindahl, Theil, Aigiur, and Krugman indexes for the Kingdom of Saudi Arabia during the year of 2017. The sample used in this study consists of four different kinds of firms (very small, small, medium, and large) of twelve sectors of activities and the wages perceived by employees in thirteen administrative areas in the Kingdom of Saudi Arabia. The data are in the forms of annual reports in the year of 2017 obtained from the General Authority for Statistics of Saudi Arabia. The results obtained certainly facilitate the comprehension of the type of income distribution to the active population by sectors and by administrative areas. As for the implication, this study's results contribute to enrich statistical data and bring added-value to the knowledge that eventually leads to understanding socioeconomic context of the country.
\end{abstract}

Keywords: Concentration; Economic Activities; Specialization 


\section{Introduction}

Examining the strength and weakness of the productive system is a crucial challenge for any national economic policy. It would be appropriate to consider the risks of a shock to economic activity at the national or local level, such as a sectoral shock or the cessation of activity of large companies with high rate of employment. The concentration and specialization of activities in a given area are essential elements for the diagnostics of the structure of the productive structure.

Thus, the objective of this study is to provide a first approximation of the evolution of concentration in the economy of the Kingdom of Saudi Arabia. Accordingly, the present study covers the year of 2017 as a reference and provides a brief analysis of the dynamics of the sectors and their dispersion by region (area). Consequently, this study gives the estimations of the indicators of concentration and specialization based on income and employment of sectors in Saudi Arabian Kingdom. This study is part of a continuing research on the subject and contributes through the results to enrich the statistical data and bring added value to the knowledge which will eventually lead to understanding the socioeconomic context of the country in question.

From the above, the concentration signifies a process in which a considerable part of the productive apparatus is controlled by a reduced or diversified number of decision-making centers, either signifying that this process leads to an egalitarian or unequal distribution structure (Morvan, 1991). On the other part, this index reveals the evolution of the dynamics of competition (Dembinski et al., 2019). In terms of inequality, which is estimated by wages, income, wealth, consumption or employment, the previous authors (Piketty, 2013; Pinçon \& Pinçon-Charlot, 2011; Bourguignon, 2012; Stiglitz, 2012; Solow, 2014; Atkinson, 2016; Deaton, 2016; Navarro, 2016; Morrisson \& Murtin, 2012 ) indicate that the situation is deteriorating. 
However, specialization in academic literature is synonymous with gaining market through competitiveness and export performance (Alessandrini \& Batuo, 2010; Chiappini, 2011). While Camatte and Gaulier (2018) distinguish between geographic specialization and sectoral specialization. On the other hand, Bas et al (2015) mentioned the combined contribution of country specialization and product specialization in their analysis.

In the literature, the models explaining specialization come mainly from trade theory, while those explaining concentration come from the theory of location. Krugman (2009) explains that it is possible to link between the three concepts of specialization, concentration, and agglomeration. Therefore, in collected work, the concepts of specialization and concentration are complementarily used to explain how externalities occur in the context of industrial agglomeration (Zheng \& Kuroda, 2013).

\section{Review of Literature}

\section{The Specialization}

The traditional theories of specialization date back to Smith (1776) and Ricardo (1817) and further developed by Ohlin (1933). The theories ensues that a country participates in international trade will specialize by increasing the production of the product for which it is relatively advantage and will leave the production for which it is at a disadvantage. These theories explain trade by factors of supply which are based on the logic of differences in costs and technological inputs as an explanatory factor of specialization. Keesing (1966) explains that specialization is based on the qualifications of the work, but Vernon (1966) has argued that innovation is a reason for specialization. As an extension of the product's life-cycle and as regards to Vernon (1966), Fontagné and Freudenberg (1999) reintroduces the quality as an element of specialization.

As for the index, which is defined in absolute terms, the concept of Herfindahl index provides information on the evolution of the 
degree of specialization intrinsic to a country and a respective sector (Rhoades (1993). In order to specify the nature of specialization (intraindustry or inter-industry), relative indexes such as the Hoover-Balassa index, the dissimilarity index, and the Krugman index should be used (Tudorel et al., 2007). It remains retained that international trade theories defend the specialization in productions for which the country has comparative advantages and even if they correspond to primary activities (Lin \& Monga, 2014). Conversely, Amiti and Freund (2010) point out that China has apparently used comparative advantages, but in reality this country remains specialized in labor-intensive goods. Within the traditional theories of international trade, liberalization brings a specialization in comparative advantages (Krishna \& Levchenko, 2013). As for Cadot et al. (2014), they propose a paper studying the phenomenon of hyper-specialization.

Concerning impoverishing specialization, Gimet et al (2010) wrote about labor-intensive industries (e.g. textile or assembly industries), which was characterized by increasing competition and the mobile nature of production units and that lead industrialists to lower labor costs while increasing productivity without consideration for human conditions. This specialization generates a decrease of wage and a gain which does not allow investing in activities generating added value. By delocalizing labor-intensive activities, developed economies are concentrating their resources on research and development activities, while developing economies will focus their resources on labor-intensive activities at the detriment of more complex activities (Gimet et al, 2010).

Elsewhere, in terms of the abundance of natural resources, Murshed and Serino (2011) reveal that the malediction of these resources appears only when the country has been unable to diversify his economy. This specialization constrains growth by inhibiting the emergence of more dynamic sectors. By the way, exports of electrical machinery and equipment assumed to be intensely interrelated between sectors (Sturgeon \& Kawakami, 2010). Wang et al. (2014) was 
thought that specialization positively contribute to industrial efficiency and regional economic performance, such as the growth of incomes, employment, labor productivity, and new start-ups. Finally, the authors retain a definition of specialization according Kuroiwa (2012) that specialization is defined as the distribution of the weight of an industrial sector in a specific region.

\section{The Concentration}

The concentration refers first to the concept of economies of scale or increasing returns, i.e. there exist gains at the junction of production in a given space. The second aspect is the fact that there is transaction costs interpreted in a sense that is generated when operators are not located in the same place and interact in their economic activities to exchange goods or ideas. Otherwise, depending on assumptions about labor mobility between regions and the structure of the economies under consideration, there can be concentration (Krugman, 1991) or specialization (Krugman \& Venables, 1996).

The Marshall-Arrow-Romer model formalizes the insight that concentration of an industry facilitates knowledge spillovers between firms and therefore innovation and growth in that industry (Feldman et al.., 1999). In the same idea, $\mathrm{Hu}$ et al. (2015) argue that the concentration of firms makes possible the sharing of knowledge and skills through formal and informal interactions between firms or individuals. Likewise, knowledge sharing may not be limited to advanced technologies, but may also include management skills and business knowledge.

Thus, Kopczewska (2017) explains that concentration might be twofold: sectoral concentration (one sector dominates over others in a given region) and geographical concentration (one region concentrates most of the employment in a given sector). Kopczewska (2017) added that the agglomeration is the spatial density of location of single firms inside one region (and possibly one sector). Specialization is the outcome of concentration and agglomeration and is interpreted in 
terms of both these measures. Longhi et al. (2014) interpret spatial or sectoral concentration through the relocation of companies or labor from one region to another. They add that another factor is able to trigger the process of concentration that should be the creation of the single market and its completion through the introduction of the Euro. Furthermore, Ke (2010) estimates the effect of the spatial concentration of industrial production on labor productivity. He used the data of Chinese cities and observed that the agglomeration caused higher productivity in large industrial and also in neighboring cities.

Combes et al. (2012) note the economic benefits of concentration and report that urban areas tend to be characterized by significantly higher growth rates, higher labor productivity, and higher wages than rural areas. The study of Martin et al. (2011) gives illustrations of the effect of concentration on productivity. From another point of view, Dijkstra (2013) reports that the majority of empirical research supports the positive effect of concentration on economic growth, such of these studies tend to analyze cities as single entities disconnected from the national production system. From another corner, Andersoon and Lööf (2011) argue that agglomeration economies provide economic reasons for the clustering of economic activities as well as the tendency for the geographical concentration of companies to persist over time.

\section{Research Method}

\section{Sample Selection and Data Sources}

The present research focused on the descriptive methodology to study, describe, and analyze the obtained results. The sample used in this study concerns employment in 4 different kinds of firms (very small, small, medium, and large firms) for 12 sectors of activity and the wages perceived by employees in 13 administrative areas of the Kingdom of Saudi Arabia. It was classified by gender (male and female) as well as the wages distributed to employees for 11 age groups (from 15 years old to over 65 years old with a difference of 5 years for each group). All these data cover the year 2017. 
The data in this study were obtained from annual reports for this period derived from General Authority for Statistics of Kingdom of Saudi Arabia. The choice of this period is justified by the availability of the information required, which is in accordance with all the studies and reports provided by the statistical authorities of the Kingdom. Moreover, these statistics are the most recent data available during that period of study.

\section{Index Measurements of Concentration and Specialization}

Between specialization and concentration, the authors join with what have been argued by Otsuka and Goto (2015) that the firms in the clustering zone are more innovative and productive, and the development of clustering, whether specialization or concentration, has a positive effect on productive efficiency at the firm level. So, this study looks at the principle indexes of concentration and specialization which are summarized in the table below:

Table 1. Summary of Empirical Literature on the Calculation of Indices for Specialization and Concentration Measurement

Authors Characteristics Formulas

\begin{tabular}{|c|c|c|c|}
\hline Concentration & $\begin{array}{l}\text { Lorenz } \\
\text { (1905) }\end{array}$ & $\begin{array}{l}\text { Index of } \\
\text { inequality } \\
\text { measurement } \\
\text { based on the } \\
\text { entropy of } \\
\text { Shannon (1948) }\end{array}$ & 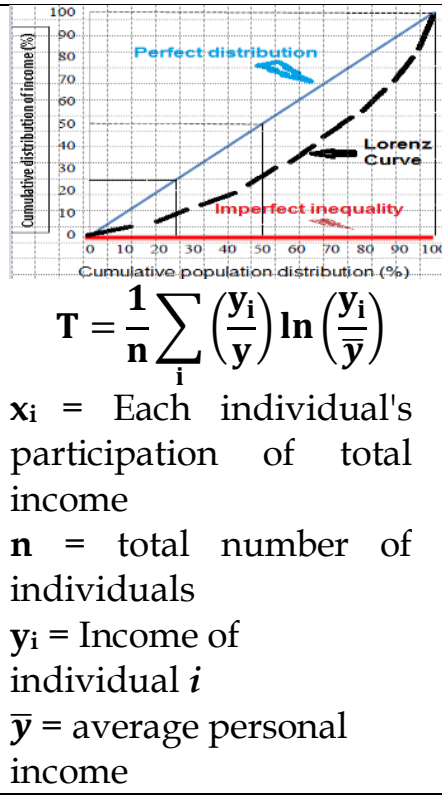 \\
\hline
\end{tabular}




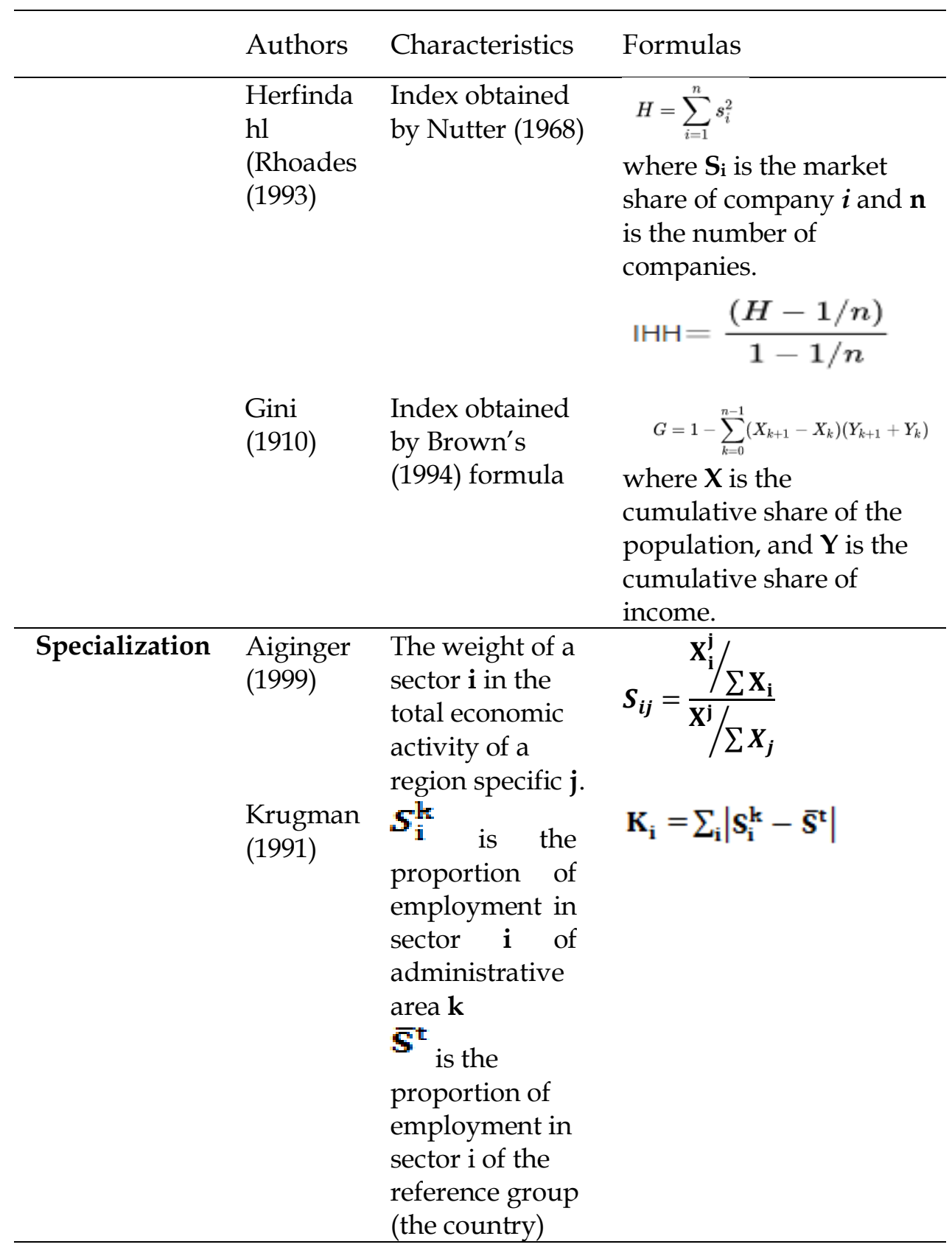




\section{Results}

\section{Concentration Measurements}

The Curve of Lorenz

The Lorenz curve is an instrument that describes the distribution of a variable evenly distributed with other variables (several individuals). It compares, on the abscissa, the distribution of cumulative individuals (sectors or regions) with the distribution, on the ordinate, of a variable of interest (wages) in the Kingdom of Saudi Arabia.

Graph 1. The Curve of Lorenz of Distribution Wages by Sector in Saudi Arabia (2017)

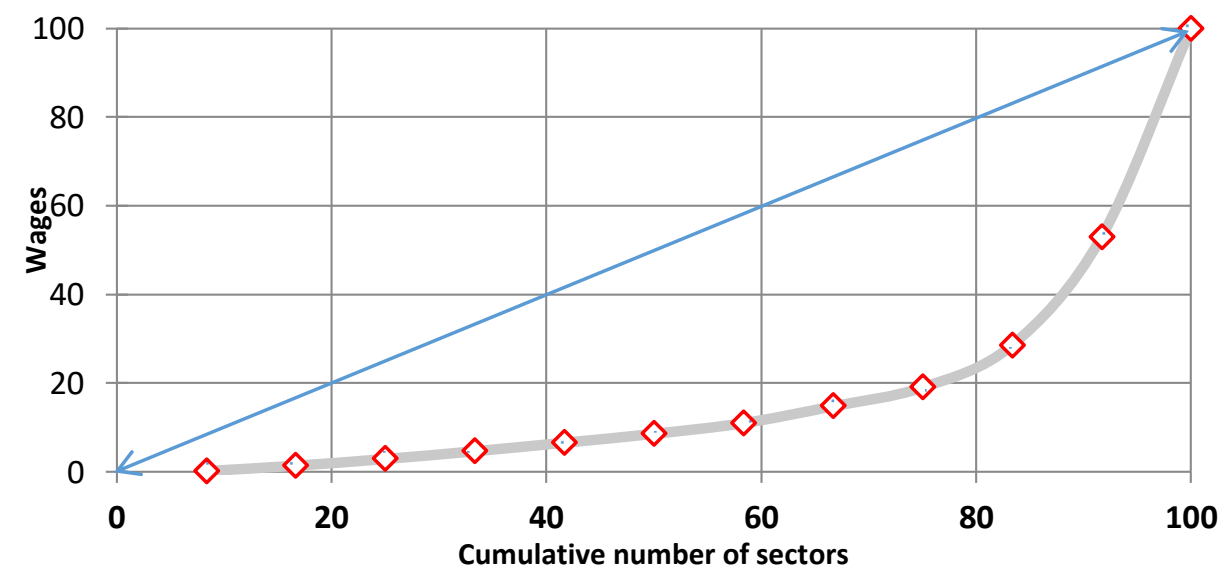

For the different sectors represented in the curve, 30\% of employees in the smallest strata cover a total of 10 sectors, i.e. $83 \%$ of the entire economic sector. The last $70 \%$ of the wages are concentrated alone in the trade and food sector and the industry sector. Consequently, the situation for both sectors (industry and trade) should be monitored by the Commercial Registry Centre with regards to the creation and deregistration of enterprises.

In order to observe and analyze the distribution of wages in Saudi Arabia by firms, the authors plot the Lorenz curve (see graph 2) which shows the most dynamic areas. 
Graph 2. The Curve of Lorenz of Distribution Wages by region In Saudi Arabia (2017)

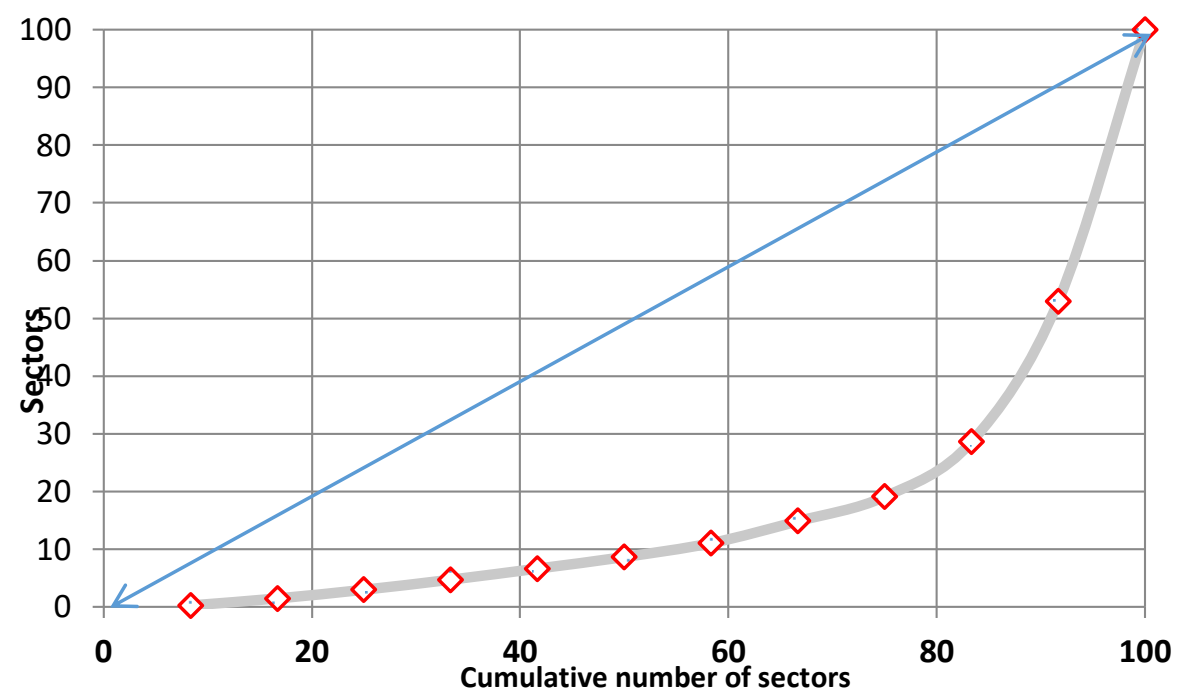

The authors note that it appears from this curve that employees in 10 out of 13 areas receive $10 \%$ of all wages paid. This situation is justified by the presence of $21.06 \%$ of employees in these 10 areas. Consequently, employment and salaries paid are concentrated on Eastern region, Makkah and Riyadh. The last two regions divide the $40 \%$ of the wages paid.

Graph 3. The Distribution Wages by Gender and Region

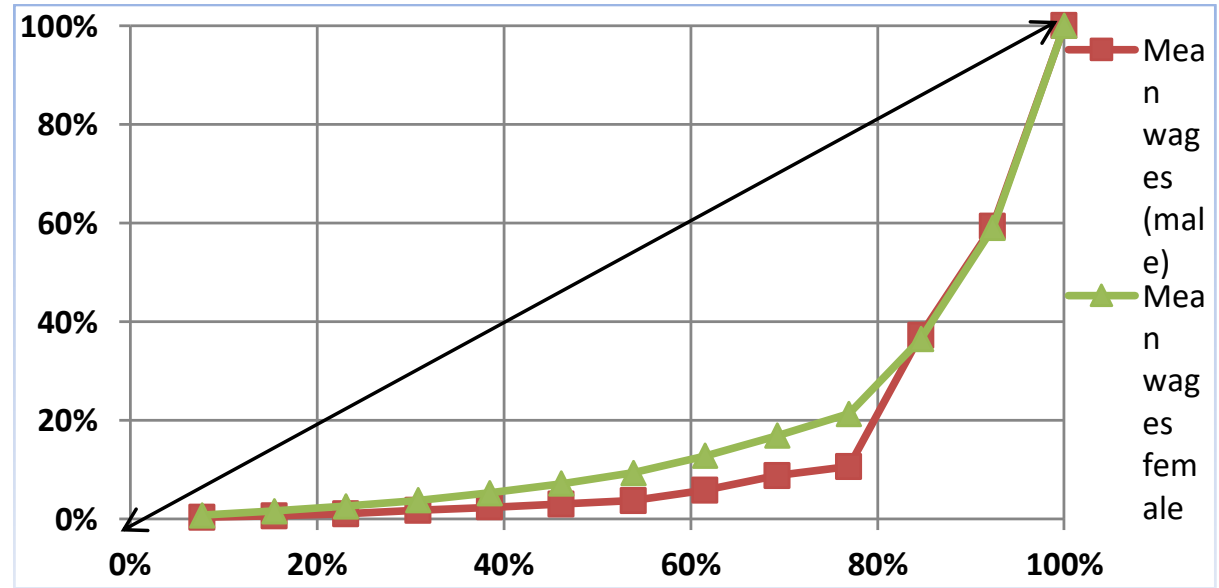

Vol. 5 No. 3, September - December 2020 
The Lorenz curve above (see graph 3) gives an overview on the distribution of employees (income) according to the different areas for employees by gender (male and female).

A situation that remains the same in all three areas (North-bord, Al-Baha, and Al-Jouf), as a result of the population level of employment, will receive only 3 and $4 \%$ of the wages paid by the economic sectors for male and female employees respectively. The situation is improving for female workers compared to male workers in the regions of Jazza, Tabuk, Aseer, Al-Qassim, and in Al Madinah. The wages received by women are double those of men. In Eastern region, the wage situation is the same for men and women. For the rest of the areas, employees in Makkah and Riyadh receive $40 \%$ of the wages. These two cities have the following characteristics, one is the capital of the Kingdom of Saudi Arabia and the other is a Saint city, a destination for more than a billion Muslims.

Graph 4. The Curve of Lorenz of Distribution Wages by Age Group

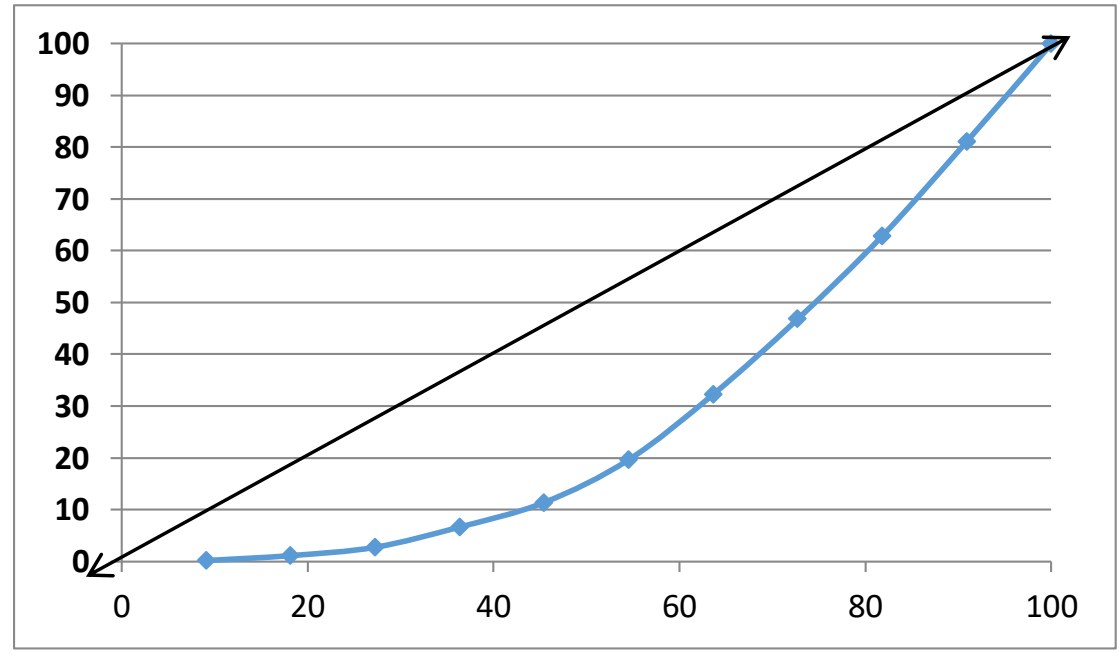

By other way, the Lorenz curve above (graph 4) is constructed to measure the distribution of employees according to the different age groups. The age groups made up of the following fringes: the under 20 years (15-19 and 20-24) and 55+ (55-59, 60-64 and 65+) receive $11 \%$ of 
the wages paid by the economic sectors. The rest of the age groups receive an almost equitable distribution of wages.

\section{The Gini Index}

The Gini Index (Gini, 1910) is used to summarize the information from the Lorenz curve. It is recognized that the Gini coefficient is between 0 and 1. When Gini is equal to zero, that represents a perfect equality (everyone has the same resources) and in the opposite, if Gini is equal to 100, it represents perfect inequality (resources are monopolized by a single category). According to the calculation used the formula in table 1 above, we obtain: (1) the Gini index of wage distribution by sector $=0.4056$, (2) the Gini index of the distribution of wages by age group $=0,01$, (3) the Gini index of wage distribution by region $($ total $)=0.5598,(4)$ the Gini index of the distribution of wages by region (male employees) $=0.5693$, and (5) the Gini index of the distribution of wages by region (female employees) $=0.3578$.

We deduce that, in terms of the sectoral distribution of wages, the Gini index measures 40.56, a level that can be classified between the European and US levels, in terms of the distribution of wealth. With regard to the distribution of wages by region, for the overall case of employees (men and women) or only employees (men), the index varies between 55.98 and 56.93, similar to Brazil, but much better than those attributed to the Latin American region and the world average. Therefore, this index represents an appreciable level. As regards to women employees, the distribution as measured by the Gini index is equivalent to 35.78 , a level that is comparable to the European Union countries, including France.

\section{The Herfindahl Index}

Various measures of diversification have been proposed in academic works. The most widely used category whether for studies in industrial economics or regional economic (Attaran \& Zwick, 1987) is based on the calculation of Herfindahl-Hirschmann concentration 
index (HHI). The HHI index can be interpreted as the equivalent number of firms of equal size that would share the employment equally. The current guidelines suggest that a market with HHI less than 1500 is not concentrated while an HHI of greater than 2.500 is highly concentrated.

Thus, as a formula in table 1 above on the data from General Authority Statistics of Saudi Arabia, and after calculating the percentage share of employment for each sector, HerfindahlHirschmann index concentration is as follows:

\section{$\mathrm{IHH}[$ by sector for 2017] $=1957$}

The formula shows a value ranging between 1000 and 2000. It indicates that employment is not highly concentrated in one economic sector compared to other sectors. Nevertheless, a predominance of the sector (Trade, Accommodation, and Food) over overall employment, the regulator (legislation and regulations currently applicable on trade, taxation, immigration, and vocational training) must ensure that a more favorable business environment is provided for this employment sector, particularly for enterprises employing between 1 and 5 . Moreover, using the same estimation method, the HHI[index by age group] is equal to:

IHHby age group in $2017=1411$

It is a value ranging between 1000 and 2000 which indicates that employment is low concentrated in one age group in comparison to other groups. Furthermore, using the same estimation method, the $\mathrm{HHI}$ [employment index for the areas] is as follows:

\section{$\mathrm{IHH}[$ by region in 2017] $=2323$}

Three regions (area) are the most job-seeking regions and these concerns Eastern Region with $19.63 \%$ followed by Makkah with $22.04 \%$ and Riyadh with $37.27 \%$. Thus, the Herfindahl-Hirschmann index by area $\mathrm{IHH}$ [by region in 2017]= 2323 denotes a concentration of 
employment in the capital Riyadh. In conclusion, as seen from the parameter chosen (sector, area or age of group), there is no distinction between a borderline case and a deregulation of concentration (all employees working) in a sector or area or age group haven't a dominance that presents a risk concentration.

From the formula above, Herfindahl-Hirschmann normalized concentration index of sector, area, and age parameters is calculated and results in several values: (1) $\mathrm{IHH}$ [normalized by sector] $=(1956$ $1 / 12) /(1-1 / 12)=2135,(2) \mathrm{IHH}$ [normalized by area] $=(2323-1 / 13) /$ $(1-1 / 13)=2517$, and (3) $\mathrm{IHH}[$ normalized by age group] $=(1411-1 / 11)$ $/(1-1 / 11)=1552$. As a deduction to these calculations, the sectorstandardized Herfindahl index is the only one that lagged above 2000 and is joined to the same analysis attributed to the regions. The table below shows the analysis according to Herfindahl-Hirschmann Index and Herfindahl-Hirschmann Normalized Index.

Table 2. Analysis of Herfindahl-Hirschmann Index and HerfindahlHirschmann Normalized Index

\begin{tabular}{|c|c|c|c|c|c|}
\hline \multicolumn{2}{|c|}{ Designations } & \multirow[t]{2}{*}{$\mathrm{IHH}<1000$} & \multirow{2}{*}{$\begin{array}{c}1000<\mathrm{IHH}< \\
2000 \\
1956.78\end{array}$} & \multirow[t]{2}{*}{$\begin{array}{c}2000<\mathrm{IHH}< \\
10000\end{array}$} & $\mathrm{IHH}=10000$ \\
\hline \multirow{3}{*}{$\begin{array}{c}\mathrm{IHH} \\
\text { by }\end{array}$} & Sector & & & & \multirow{6}{*}{ / } \\
\hline & Region & & / & 2323.26 & \\
\hline & Age & & 1411.05 & / & \\
\hline \multirow{3}{*}{$\begin{array}{c}\mathrm{IHH}^{*} \\
\text { by }\end{array}$} & $\begin{array}{l}\text { Group } \\
\text { Sector }\end{array}$ & / & & 2134.57 & \\
\hline & Region & & 7 & 2516.78 & \\
\hline & $\begin{array}{l}\text { Age } \\
\text { Group }\end{array}$ & & 1552.06 & / & \\
\hline \multicolumn{2}{|c|}{ Conclusion } & $\begin{array}{c}\text { No } \\
\text { concentration }\end{array}$ & $\begin{array}{c}\text { Low } \\
\text { concentration }\end{array}$ & $\begin{array}{c}\text { Consequent } \\
\text { Concentration }\end{array}$ & $\begin{array}{c}\text { Concentration } \\
\text { Maximum }\end{array}$ \\
\hline
\end{tabular}

The Entrophy Index

The general entropy index in table 1 is subdivided into two elements expressed according to the following formulas: $\mathbf{T}=\mathbf{T}_{\mathbf{1}}+\mathbf{T}_{\mathbf{2}}$ 
or $\mathbf{T}=\mathbf{T}_{\text {intra }}+\mathbf{T}_{\text {inter }}$ (intra-group entropy measuring inequalities within each group and inter-group entropy measuring inequalities between different groups).

$T_{\text {intra }}=\mathrm{T}_{1}=\sum_{\mathrm{j}} \mathrm{v}_{\mathrm{j}} \sum_{\mathrm{i}} \mathrm{z}_{\mathrm{ij}} \ln \left(\mathrm{z}_{\mathrm{ij}} \mathrm{n}_{\mathrm{j}}\right)$ and $T_{\text {inter }}=\mathrm{T}_{2}=\sum_{\mathrm{j}} \mathrm{v}_{\mathrm{j}} \ln \left\langle\frac{\mathrm{v}_{\mathrm{j}} \mathrm{n}_{\mathrm{n}_{\mathrm{j}}}}{\mathrm{w}}\right.$

with:

$\mathbf{v}_{\mathbf{j}}=$ participation of group $\mathbf{j}$ in total income

$\mathbf{z}_{\mathbf{i j}}=$ participation of individual $\mathbf{i}$ in the income of group $\mathbf{j}$

$\mathbf{n}_{\mathbf{j}}=$ number of individuals in group $\mathbf{j}$

$\mathbf{n}=$ total number of individuals.

$\mathbf{T}$ by region $=1.2770$ which results of $\mathbf{T}_{1}=1.02109+\mathbf{T}_{2}=0.25597$,

Index of Theil reveals that inequality between the two groups (male and female) of wage is more important in total inequality than inequality between regions.

\section{Specialization Measurements}

The specialization of the production or employment of an area in relation to the country is understood by comparing the sectoral structure of production or employment of area with the sectoral structure of production of the country, and by using the production or employment of the country as a reference element (Vermaut, 2003). The specialization indexes (Aiginger, 1999) which is mentioned in table 1 represent the expression of the ratio of the weight of sectors (i) in the total economic activity of a specific employment area (j) in relation to the relative weight of the same activity at national level. It is obtained from the following simplified report:

Specialization index $S_{\mathrm{ij}}=$ (Sector employments in the territory $\mathrm{X}_{\mathrm{ij}}$ ) / (Total employment in the territory $\mathrm{X}_{\mathrm{i}}$ )

The results of sectoral specialization measure the ratio between the sectoral structure of the employment area under study and that of 
the entire Kingdom of Saudi Arabia. The authors define three classes: over-representation (specialization index >1.25), in the average (between 0.75 and 1.25), and under-representation $<0.75$. The following graph is derived after the calculations according to the above formula in table 1.

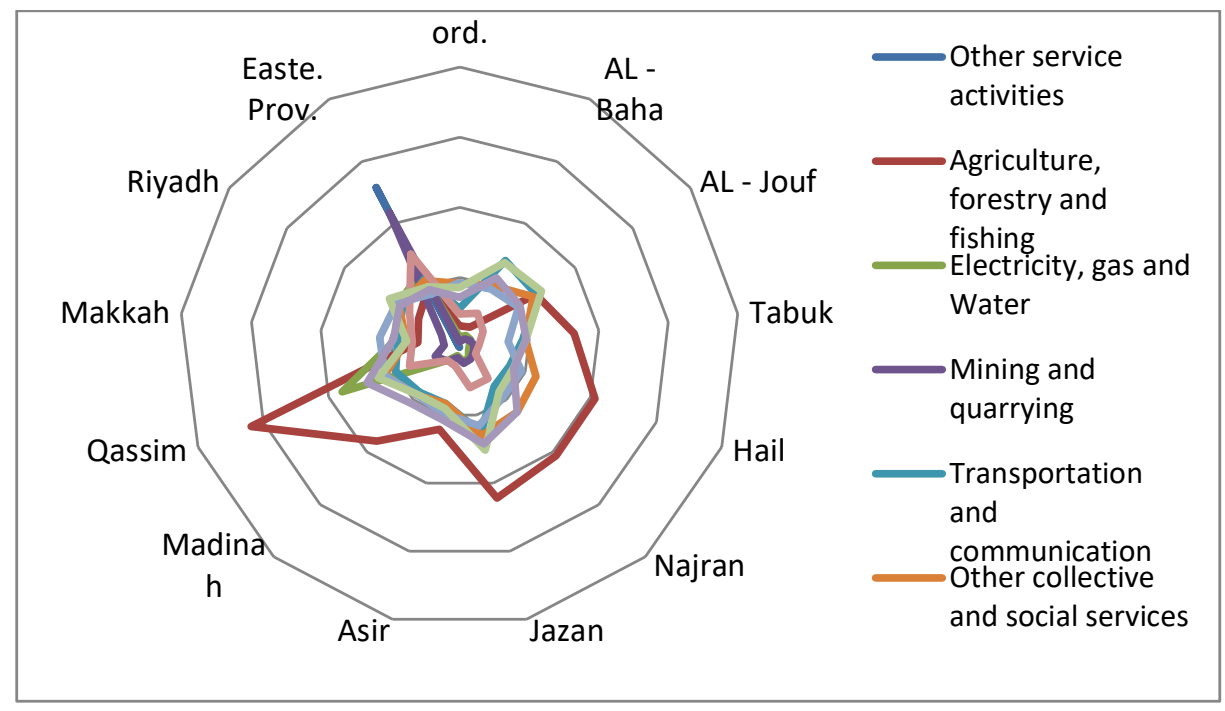

Figure 1. Specialization of Activities by Administrative Area

\section{Krugman Specialization Index}

The Krugman index is therefore the sum of the differences in absolute value between the industrial structure of the area and that of the rest of the reference territory defined according to the formula in the table 1. For our case study, the economic activities or industrial sector (structure) is measured across its employment base. It measures the absolute distance between the relative importance of a sector and then adds all sectors together to generate an index.

The Krugman index will be equal to zero $\left(K_{i}=0\right)$, so, the area in terms of employment is perfectly similar to the rest of the territory (country); the area has no specialization because it perfectly reflects the structure of the territory. However, if the area is entirely specialized in 
activities, the Krugman index will be equal to $100 \%$ and the authors said a perfectly specific area. If the value of this index is comprised between $0 \%$ and $20 \%$, the areas which correspond are relatively specialized. Finally, if the value of Krugman index is between $20 \%$ and $100 \%$, the authors can affirm that the areas associated to this value are very specialized.

Thus, the estimates of the Krugman specialization indexes for each zone according to the formula presented in table 1, whose values range from $0.46 \%$ to $60.75 \%$, are illustrated in the following figure.

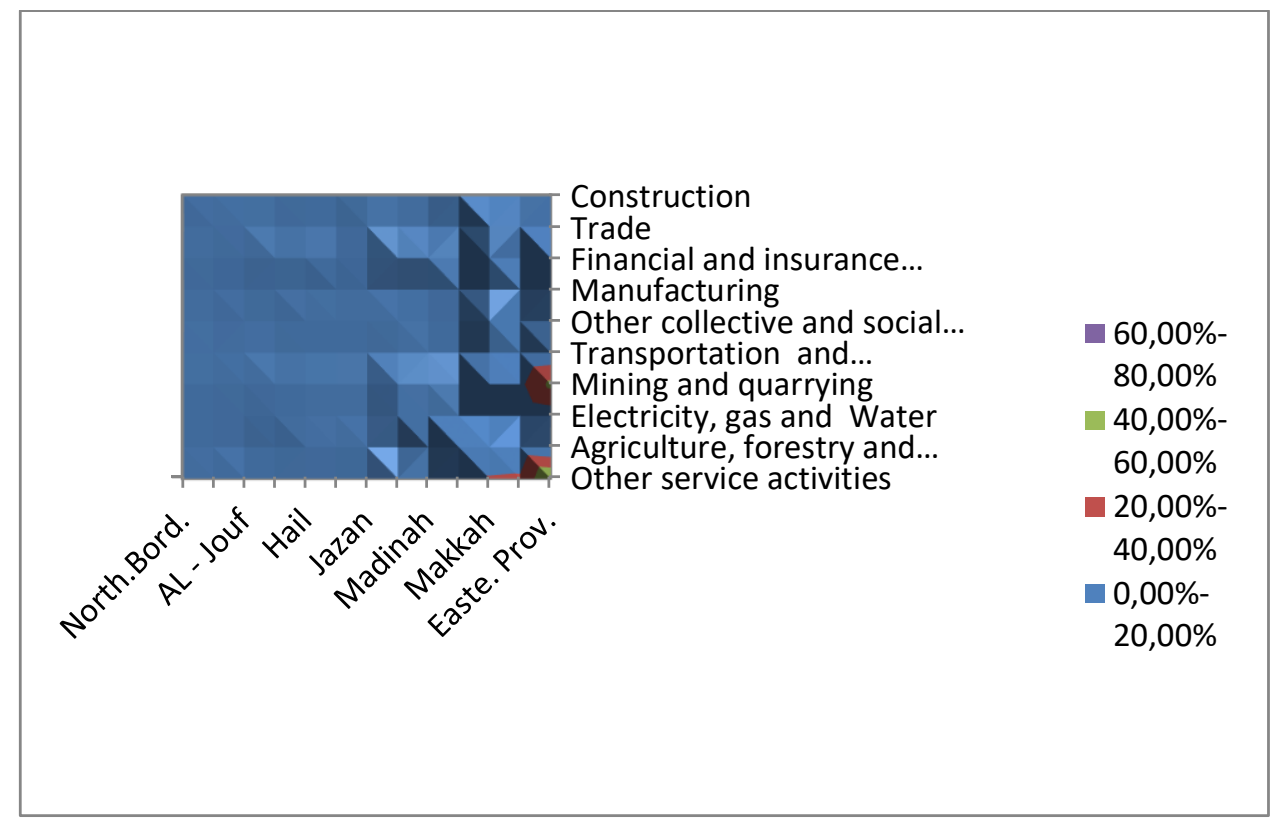

Figure 2. Specialization of the Administrative Areas of the Kingdom of Saudi Arabia According to the Krugman index

From the figure, the authors observe that the majority of the administrative areas shown in blue have a Krugman index less than $20 \%$, which indicates that these territories are not very specialized, with the exception of Eastern Provence, which is more specialized in the mining and quarrying sector. 


\section{Discussion}

Indeed, in a context of international competitiveness, territories are the source of many of the diversity. Specialization and concentration factors determine the success of business creation in transport, energy, telecommunications, employment areas, and training. In addition, the era of the knowledge-based economy marked by the predominance of tertiary activities, innovation and dematerialization, and the ability to attract and retain foreign direct investment are several factors that help to cluster and will potentially result in the local development.

Therefore, the analysis of local determinants (material and immaterial factors) implies identifying the distinctive characteristics of territories through the estimation of concentration and specialization that can contribute to the understanding of the trajectories of enterprises (creation, disappearance, increase, and foreign direct investment). This estimation constitutes a warning factor regarding the trends of the sectors of activity and their impacts on employment, the distribution of the wealth, and the growth at the level of each administrative area.

On the theoretical aspect, the authors have been limited to simplifying the notions of concentration and specialization in order to estimate them without any ambiguity, whereas these notions have been discussed largely in the academic literature where researchers have demonstrated the role, weight, effects, and their importance on the national economy. For the results obtained and discussed below about the Kingdom of Saudi Arabia, they lead us to deduce that more effort is needed to achieve more equitable distribution of wages between regions and sectors, although the obtained results are significant and can be compared to some European countries.

For the Herfindhal-Hirshmann index, the result of this study confirms that there is no monopoly or dominance situation with regard to the dispersion of firms by group or by sector. It gives a signal of 
greater concentration in given administrative areas. In a view of the vastness of the territory of the Kingdom of Saudi Arabia and the extreme natural conditions, the specialty of the geographical economy is better equipped to develop this aspect. It can be considered as an effort to enhance the concentration quality of economic activities in order to distribute equal wages.

Moreover, with regards to Theil's index, it reveals the inequality between men and women in the wages perceived by firms. It is an index based on macro-economic aggregates, which can be confirmed on what scale in the case of a national survey conducted among a representative sample of firms (micro-economy-oriented study). Finally, for specialization, the two indexes studied above suggest that the two administrative areas (Qassim and Eastern Provence) are specialized.

\section{Conclusion}

This study sheds some light on several indicators for understanding the structure of economic activities in terms of concentration and specialization in the Kingdom of Saudi Arabia. Drawing on the data in the forms of annual reports of firms obtained from General Authority of Statistics of Saudi Arabia in 2017, the results show that specialization and concentration factors determine the success of business creation in transportation, energy, telecommunications, employment areas, research, trainings, and other economic activities. This study suggests that compelling efforts are highly needed to achieve more equitable distribution of wages between regions and sectors in the kingdom of Saudi Arabia, although the obtained results are significant and can be compared to some European countries. As same as other previous research, this study acknowledges a limitation that the sample period used is only limited in the year of 2017. Therefore, further studies that examine similar research area can conduct an immense project by employing larger samples both in terms of period and number. 


\section{Acknowledgement}

The authors extend their appreciation to the Deanship of Scientific Research at King Khalid University for funding this work through research groups' program under grant number GRP 299-40.

\section{References}

Aiginger K., (1999). Do industrial structures converge? A survey on the empirical literature on specialization and concentration of industries. Austrian Institute of Economic Research (WIFO), No 116, Vienna.

Alessandrini, M. \& Batuo, M. E. (2010). The trade specialization of SANE: evidence from manufacturing industries. The European Journal of Comparative Economics. 7(1), 145-178.

Amiti, M. \& Freund, C. (2010). The Anatomy of China's Export Growth. In Feenstra, R. C. \& Wei, S. J. China's growing role in World Trade. Chicago: University of Chicago press.

Andersoon, M. \& Lööf, H. (2011). Agglomeration and productivity: Evidence from firm-level data. Annual Regional Science. 46, 601620.

Attaran, M. \& Zwick, M. (1987). Entropy and other measures of industrial diversification. Quarterly Journal of Business and Economics, 26(1), 17-34.

Atkinson, A. B. (2016). Inégalités. Traduce by F. Chemla and P. Chemla. Éditions du Seuil. Paris : France.

Bas, M., Fontagné, L., Martin, P. \& Mayer, T. (2015). À la recherche des parts de marché perdues. Les notes du Conseil d'analyse économique. 23(Mai).

Bourguignon, F. (2012). La mondialisation de l'inégalité. Coédition SeuilLa République des Idées. France.

Brown, M. C. (1994). Using Gini-style indices to evaluate the spatial patterns of health practitioners: theoretical considerations and an 
application based on Alberta data. Social Science and Medicine, 38 (9), 1243-1256.

Cadot, O. (2014). Export big hits: self-discovery, demand shocks, or idiosyncratic. International growth center working paper.

Camatte, H. \& Gaulier, G. (2018). Spécialisation sectorielle et rechute du commerce extérieur français en 2014-2016. Bloc-Notes Éco. Banque de France. 25 juillet.

Chiappini, R. (2011). Comment mesurer la compétitivité structurelle des pays dans les équations d'exportation? L'Actualité économique. Société Canadienne de science économique. 87(1), 31-57.

Combes, P.P., Duranton, G., \& Gobillon, L. (2011). The identification of agglomeration economies. Journal of Economic Geography. 11(2), 253-266.

Deaton, A. (2016). La grande évasion: santé, richesse et origine des inégalités. Presses Universitaires Françaises.

Dembinski, Paul H. Schoenenberger, Alain M. \& Cooremans, C. (2019). Affaiblissement de la dynamique de marché ? Étude pilote sur l'évolution de la concentration au sein de l'économie suisse. Analyse et études économiques. Rapport final. Geneva. Switzerland.

Dijkstra, L. (2013). Why investing more in the capital can lead to less growth. Cambridge Journal of Regions, Economy and Society. 6, 251268.

Feldman, M. P. \& Audretsch, D. (1999). Innovation in cities: sciencebased diversity, specialization and localized competition. Eur. Econ. Rev. 43, 409-429.

Fontagné, L. \& Freudenberg, M. (1999). Marché unique et développement des échanges. Économie et Statistique. 326(1), 7195.

Gimet, C., Guilhon, B., \& Roux, N. (2010). Fragmentation and immiserising specialization: the case of the textile and clothing sector. Working Paper GATE 2010-03. 
Gini, C. (1910). Indici di concentrazione e di dependenza. in Biblioteca dell Economista. Torino. Unione Tipografico R Editrice Torinese. XX (1a \& 2a), 453-469.

Heckscher, E. (1919). Effect of foreign trade on the distribution of income. Reproduced at readings in the theory of international trade. Philadelphia: Blakiston.

Hu, C., Xu, Z., \& Yashiro, N. (2015). Agglomeration and Productivity in China: Firm Level Evidence. China Economic Review. 33, 50-66.

Ke, S. (2010). Agglomeration, productivity, and spatial spillovers across Chinese cities. The Annals of Regional Science. 45(1), 157-179.

Keesing, D. B. (1966). Labor skills and comparative advantage. American Economic Review. 56, 249-258.

Kopczewska, K. (2017). Cluster-based measurement of agglomeration, concentration and specialization. Measuring Regional Specialization. Palgrave Macmillan, Cham. Available in https://doi.org/10.1007/978-3-319-51505-2_2 (visited in October 2020).

Krishna, P. \& Levchenko, A. (2013). Comparative advantage, complexity, and volatility. Journal of Economic Behavior and Organization. 94, 314-329.

Krugman, P. (1991). Geography and trade, Leuve: Leuven University Press et Cambridge. MA: The MIT Press.

Krugman, P. \& Venables, A. (1996). Integration, specialization and adjustment. European Economic Review. 40(December), 59-967.

Krugman, P. (2009). The increasing returns revolution in trade and geography. The American Economic Review. 99(3), 561-571.

Kuroiwa, I. (2012). Integration and the location of industries: The Case of less developed East Asian Countries. Institute of Developing Economies. IDE-JETRO. Japan.

Lin, J. Y. \& Monga, C. (2014). The Evolving paradigms of structural Change. In Currie-Alder. International development: ideas, experience, and prospects. Oxford University Press. pp. 277-274. 
Lorenz, M. O. (1905). Methods of measuring the concentration of wealth. Publications of the American Statistical Association. 9(70), 209-219.

Longhi, C., Musolesi, A., \& Baumont, C. (2014). Modeling structural change in the European metropolitan areas during the process of economic integration. Economic Modelling. 37, 395-407.

Martin P., Mayer, T., \& Mayneris, F. (2011). Spatial concentration and plant-level productivity in France. Journal of Urban Economics. 69(2), 182-195.

Morrisson, C. \& Murtin, F. (2012). Vers un monde plus égal?. Revue d'économie du développement. 20(2), 5-30.

Morvan Yves. (1991). Fondements d'économie industrielle (Second Edition). France Economica: Paris.

Murshed, S. Y. \& Serino, A. S. (2011). The pattern of specialization and economic growth: the resource curse hypothesis revisited. Structural Change and Economic Dynamics. 22, 151-161.

Navarro, M. (2016). Les inégalités de revenus. Cursus. France: Paris.

Nutter, G. (1968). Industrial concentration. International Encyclopaedia of the Social Sciences. New York, 218-222.

Ohlin, B. G. (1933). Interregional and International Trade. Cambridge: Harvard University Press.

Otsuka, A. \& Goto, M. (2015). Regional policy and the productive efficiency of Japanese industries. Regional Studies. 49(4), 518-531.

Piketty, T. (2013). Le Capital au XXIe siècle. Le Seuil, coll. Les livres du nouveau monde. Paris: France.

Pinçon, M. \& Pinçon-Charlot, M. (2011). Être riche, la classe. Entretien Projet. 2(1), 21-27.

Ricardo, D. (1817). Les principes de l'économie politique et de l'impôt. Paris: Flammarion.

Rhoades, S. A. (1993). The herfindahl-hirschman index. Fed. Res. Bull., 79, 188.

Samuelson, P.A. (1948). International Trade and the Equalization of Factor Prices. Economics Journal. 58(230), 163-184. 
Shannon, C.E. (1948). A mathematical theory of communication. The Bell System Technical Journal. 7(2), 379-423

Smith A. (1776). Recherches sur la nature et les causes de la richesse des nations. Paris: Garnier-Flammarion.

Solow, R. M. (2014). Capital in the Twenty-First Century. The New Republic. Retrieved from https://newrepublic.com/article/117429/capital-twenty-first-century-thomas-piketty-reviewed, visited in november 2020.

Stiglitz, J. E. (2012). Le prix de l'inégalité, traduce by Chemla, Françoise: Éditions les liens qui libèrent. France: LLL.

Sturgeon, T. J. \& Kawakami, M. (2010). Global value chains in the electronics industry was the crisis a window of opportunity for developing countries?. Policy Research Working Paper 5417.

Theil, Henri. (1967). Economics and Information Theory. Amsterdam: North Holland.

Tudorel, A. \& Iacob, A.I. \& Liviu, V. B. (2007). Tendencies in the Romania's Regional Economic Development during the Period 19912004. MPRA Paper 6886. University Library of Munich, Germany.

Vermaut, A. (2003). Concentration spatiale des activités économiques et spécialisation des territoires approche théorique et application aux régions et zones d'emploi françaises. Thèse de doctorat. Université des sciences et technologies de Lille faculté des sciences économiques et sociales. France.

Vernon, R. (1966). International Investment and International Trade in the Product Cycle. The Quarterly Journal of Economics. 80(2), 190207.

Wang, L., Madhok, A. \& Xiao, L. S. (2014). Agglomeration and clustering over the industry life cycle: Toward a dynamic model of geographic concentration. Strategic Management Journal. 35(7). 995-1012.

Zheng, D. \& Kuroda, T. (2013). The impact of economic policy on industrial specialization and regional concentration of China's high-tech industries. The Annals of Regional Science. 50(3), 771-790. 